\title{
An in vitro co-culture model of esophageal cells identifies ascorbic acid as a modulator of cell competition
}

\author{
Lauren MF Merlo ${ }^{1 *+}$, Rachelle E Kosoff ${ }^{2 \dagger}$, Kristin L Gardiner ${ }^{1}$ and Carlo C Maley ${ }^{1,3}$
}

\begin{abstract}
Background: The evolutionary dynamics between interacting heterogeneous cell types are fundamental properties of neoplastic progression but can be difficult to measure and quantify. Cancers are heterogeneous mixtures of mutant clones but the direct effect of interactions between these clones is rarely documented. The implicit goal of most preventive interventions is to bias competition in favor of normal cells over neoplastic cells. However, this is rarely explicitly tested. Here we have developed a cell culture competition model to allow for direct observation of the effect of chemopreventive or therapeutic agents on two interacting cell types. We have examined competition between normal and Barrett's esophagus cell lines, in the hopes of identifying a system that could screen for potential chemopreventive agents.
\end{abstract}

Methods: One fluorescently-labeled normal squamous esophageal cell line (EPC2-hTERT) was grown in competition with one of four Barrett's esophagus cell lines (CP-A, CP-B, CP-C, CP-D) under varying conditions and the outcome of competition measured over 14 days by flow cytometry.

Results: We demonstrate that ascorbic acid (vitamin C) can help squamous cells outcompete Barrett's cells in this system. We are also able to show that ascorbic acid's boost to the relative fitness of squamous cells was increased in most cases by mimicking the $\mathrm{pH}$ conditions of gastrointestinal reflux in the lower esophagus.

Conclusions: This model is able to integrate differential fitness effects on various cell types, allowing us to simultaneously capture effects on interacting cell types without having to perform separate experiments. This model system may be used to screen for new classes of cancer prevention agents designed to modulate the competition between normal and neoplastic cells.

\section{Background}

Cancer progression is an evolutionary process by which heterogeneous populations of neoplastic clones compete with each other and normal cells for space and resources [1]. All interventions, whether preventive or therapeutic, are attempts to perturb this process of clonal evolution. Ultimately, if a treatment kills or disrupts neoplastic cells, some cell type must grow back in their place. Our interventions are implicit attempts to bias this competition in favor of normal cells. Successful prevention and therapeutic interventions can modulate the

\footnotetext{
*Correspondence: Imf.merlo@gmail.com

† Contributed equally

'The Wistar Institute, 3601 Spruce St., Philadelphia, PA 19104, USA Full list of author information is available at the end of the article
}

dynamics of competition in one of two ways, either

1) neoplastic cells may be negatively affected by a therapy or intervention, thus reducing the competitive advantage of these cells relative to normal cells. Most traditional interventions employ this strategy of reducing the fitness of neoplastic cells by killing or preventing proliferation. Alternatively,

2) the "normal" cells may gain a competitive advantage from a mitogen or survival factor added to the neoplastic environment that differentially affects cell fitness, allowing the normal cells to outcompete the neoplastic cells, a strategy we refer to as "benign cell boosters" [2]. Computational models suggest this may be an effective strategy to harness clonal competition to prevent cancer [2].

\section{C) Biomed Central}


Clear documented examples of clonal expansion [3-6] demonstrate that there is interaction and competition between heterogeneous clones within a neoplasm and those clones may displace normal cells in a tissue. Although competition between heterogeneous cell types is a fundamental property of progression and therapeutic intervention [7-9], the mechanism of competition is incompletely understood and only a few studies [10-12] have attempted to directly quantify the dynamics of competition between normal and neoplastic cells [13]. Here, we define competition as interaction between two cell types such that the cell types exhibit behavior or dynamics when together that is not present when each cell type is grown alone. This is based on an ecological definition of competition, where the fitness of one population negatively affects the fitness of another, and can be the result of both changes in proliferative or death processes. Early work by Heppner and Miller demonstrated that subpopulations of mouse mammary tumor cells could affect each other's growth when reinjected into mice [14]. More recent studies of cell competition in cancer have found that cells containing a mutant tumor suppressor $l g l$ or a mutant $l g l$-binding protein, mahj, can be competitively eliminated [15]. Indirect measures from human neoplasms suggest that oncogenic mutations may only increase clone relative fitness by $0.5 \%$ in clonal competition [16]. Transformed cells have also been found to exhibit different behavior when surrounded by normal cells compared to other transformed cells [17-19]. In Drosophila, cells containing extra copies of the myc proto-oncogene can outcompete wild-type cells [20]. While there is certainly extensive interest in competition in cancer $[13,21,22]$, cell competition plays an important role in other cellular systems, such as the developmental programme of Drosophila melanogaster [23-25]. In cancer studies, most standard in vitro systems do not include normal cells or multiple neoplastic cell types and thus fail to model the process of competition that is the true target of our interventions. Here, we have developed a cell culture model system in which competition dynamics can be directly measured.

Barrett's esophagus (BE) provides an ideal model in which to test the evolutionary dynamics of competition. In an environment of chronic gastroesophageal reflux, in some patients, BE cells (specialized intestinal metaplasia) replace normal squamous tissue in the distal esophagus [26]. Acid suppression alone is not sufficient to allow the squamous cells to outcompete Barrett's cells and cause regression, though the combination of wounding, via biopsies or ablation, along with acid suppression, can lead to regrowth of squamous tissue [26-28]. BE is of clinical importance because it is the only known precursor of esophageal adenocarcinoma
(EA) and is associated with a relative risk of esophageal adenocarcinoma of 30-125 compared to the general US population of similar age [29]. However, the natural history of $\mathrm{BE}$ is typically nonprogressive, with the risk of progression to EA approximately $0.6-0.7 \%$ /year [30,31]. Thus, there may be an extensive time period in which to intervene in the process of progression to prevent EA and a unique opportunity for chemoprevention given that patients likely have BE for many years before EA develops. BE lacks a physiologically realistic animal model system for investigating potential chemopreventive agents, the best known being a surgical anastomosis model in the rat [32-36]. Therefore, there is a need for a simple model system for screening compounds that may affect the establishment and progression of BE.

We have developed a sensitive in vitro model of competition between Barrett's esophagus and squamous esophageal cells that may be used to identify a new class of interventions, explicitly designed to modulate competition in favor of normal cells. Co-cultures of an esophageal squamous cell line with each of four BE cell lines were evaluated over 14 days for changes in the proportion of cells of each population under varying concentrations of the antioxidant vitamin $C$, as well as vitamin $\mathrm{E}$ and epidermal growth factor $[37,38]$. In addition to exposure under normal cell culture growth conditions, we also examined the effect of daily acid pulses on vitamin C competitions to better replicate the reflux conditions of the lower esophagus in patients with BE. Results demonstrate that vitamin $\mathrm{C}$ reduces growth of $\mathrm{BE}$ cells relative to normal squamous cells, giving a competitive advantage to normal squamous cells at physiologically relevant concentrations of vitamin C. Under acidic conditions, the advantage conferred to normal cells by vitamin $C$ is generally greater. This is consistent with recent epidemiological data suggesting that vitamin $\mathrm{C}$ may help prevent progression from Barrett's esophagus to esophageal adenocarcinoma $[39,40]$.

\section{Methods}

\section{Cell Lines}

Four hTERT transformed Barrett's esophagus (BE) cell lines (gift of P. Rabinovitch, University of Washington, Seattle WA) were used in competition experiments. These cell lines, CP-A, CP-B, CP-C, and CP-D, were established from $\mathrm{BE}$ cells isolated from 4 different patients. The CP-A cell line (9p LOH, TP53 $\left.{ }^{\mathrm{wt}}, 5 \mathrm{q} \mathrm{LOH}\right)$ was established from an area of nondysplastic metaplasia and the CP-B (9p LOH, 17p LOH, TP53 $\left.{ }^{\text {mut }}\right)$, CP-C (9p LOH, $17 \mathrm{p} \mathrm{LOH}$, TP $53^{\text {mut }}$ ), and CP-D (9p LOH, 17p $\mathrm{LOH}, \mathrm{TP}^{\mathrm{mut}}{ }^{\mathrm{m}}$ ) cell lines were established from areas of high-grade dysplasia. All 4 BE lines are aneuploid $[41,42]$. Normal esophageal squamous cells that had been hTERT transformed (EPC2-hTERT) were also 
used (gift from A. Rustgi, University of Pennsylvania, Philadelphia PA). All BE cell lines were adapted to serum-free conditions in keratinocyte serum-free (KSF) medium supplemented with bovine pituitary extract and epidermal growth factor (EGF) (Invitrogen Corp. Carlsbad, CA) by serial passaging of cell lines into successively lower concentrations of serum until the cell lines survived without serum present. BE cell line identities were verified with the Identifiler PCR Amplification kit (Applied Biosystems).

\section{Cell Labeling}

Esophageal squamous cells (EPC2-hTERT) were transduced with an eGFP-expressing lentivirus (gift of $\mathrm{M}$. Herlyn, Wistar Institute, Philadelphia, PA). Transduced cells were sorted twice by flow cytometry to purify eGFP expressing cells. The stability of the fluorescent tag was monitored throughout each experiment, and it was maintained at $100 \%$ of the original fluorescence for 14 days, the duration of competition experiments. Labeled EPC2 cell lines were tested for evolutionary neutrality of the fluorescent label by competition between labeled and unlabeled populations of the EPC2 cells to confirm that the labeled cells do not generate a differential response to the mitogen of interest. We verified that there is no interaction between ascorbic acid and the eGFP fluorescent label (Additional File 1, Figure S1).

\section{Co-culture of squamous and BE cells without acid}

Competitions consisted of one unlabeled (non-fluorescent) BE cell line and one eGFP-labeled squamous cell line. These were seeded with a total of $2 \times 10^{5}$ cells (50\% from each cell line) into a $60 \mathrm{~mm}$ plate (Greiner, USA Scientific). Initial seeding ratios were measured by flow cytometry. Cells were cultured in KSF medium (Invitrogen) with $50 \mathrm{U} / \mathrm{mL}$ penicillin and $50 \mathrm{ug} / \mathrm{mL}$ streptomycin supplemented with the agent of interest for 14 days, with media changes every 2-3 days. Vitamin $C$ (ascorbic acid, Fisher Scientific) stocks were made every 5 days at $1000 \mathrm{X}$ the final concentration in PBS and filter sterilized $(0.22 \mu \mathrm{m}$ filter $)$. Competitions were performed at $0,50,150$, and $500 \mu \mathrm{M}$ concentrations of ascorbic acid to approximate physiologically relevant conditions based on plasma and mucosal concentrations of this compound $[43,44]$. The effect of two other compounds, $\alpha$-tocopherol (Sigma) and EGF (Gibco), was measured using an identical protocol (For methods, see Additional File 1, Figures S2, S3). Competitions were passaged by complete trypsinization every 3-4 days. $0.25 \%$ Trypsin (Gibco) was inhibited with addition of $250 \mathrm{mg} / \mathrm{L}$ soybean trypsin inhibitor (Gibco) in PBS. Trypsinized plates were examined by light microscopy to verify that no cells still adhered to the plate. For each experiment, there were 4 sampling points, starting 3-4 days after initial seeding. Competitions were reseeded with $20 \%$ of the cells after trypsinization. Flow cytometric analysis (Beckman Coulter EPICS XL flow cytometer) was performed on days 3, 7, 10 and 14 after seeding to discriminate between the fluorescent normal squamous cells and the non-fluorescent BE cells.

\section{Acid Pulsing of co-cultured squamous and BE cells}

Co-culture methods are as described above with the exception that for acid pulsed cells, competitions were pulsed for 6 minutes daily with $\mathrm{pH} 3.5 \mathrm{PBS}$ at $37^{\circ} \mathrm{C}$, rinsed twice with neutral $\mathrm{pH}$ PBS and fresh media was replaced in each plate. These competitions were reseeded with $15 \%$ of the cells after trypsinization and flow cytometric analysis (Beckman Coulter EPICS XL flow cytometer) performed on days 3, 7, 10 and 14 after seeding.

\section{Growth of Cell Lines in Monoculture}

For each of the $4 \mathrm{BE}$ cell lines (CP-A, CP-B, CP-C, CPD) and 1 esophageal squamous cell line (EPC2), 10,000 cells were seeded into a 6-well plate containing KSF media (Invitrogen) with or without $100 \mu \mathrm{M}$ ascorbic acid. After 6 days of growth, cells were trypsinized and counted (Nucleocounter, New Brunswick Scientific).

\section{Immunofluorescence of Proliferation and Apoptosis Fixation of cells}

Cells from competition experiments were fixed with $2 \%$ PFA in PBS for 20 minutes at room temperature, centrifuged at $485 \times \mathrm{g}$ for 5 minutes, and washed twice with PBS. PFA was made from a $16 \%$ stock solution (Electron Microscopy Sciences, Hatfield, PA) once per month and stored at $4^{\circ} \mathrm{C}$ in the dark. Fixed cells were stored in the dark at $4^{\circ} \mathrm{C}$ in PBS until analysis.

\section{Phospho-HistoneH3}

PHH3 was probed as a marker of proliferation. Fixed cells were blocked with $5 \%$ goat serum for 30 minutes at room temperature. After 2 rinses with a wash buffer of $0.1 \%$ saponin (Acros) in PBS, the primary antibody (Sigma H0412) was added to each sample at a dilution of 1:500 in the wash buffer. After 1 hour at room temperature, 3 washes were performed. The secondary antibody (goat anti-rabbit Alexa Fluor 488) was added at 1:100 dilution in wash buffer. This was followed by 3 more washes. Samples were analyzed by flow cytometry (Beckman Coulter EPICS XL flow cytometer). Postacquisition analysis was performed with Flowjo (Version 8.7.1).

\section{Active Caspase-3}

The cleaved, active form of Caspase-3 (Sigma C8487) was probed as a marker for apoptosis at a single time point at the end of the competition period. The protocol 
followed was the same as for $\mathrm{PHH} 3$, with a 1:500 dilution of the primary antibody and the same secondary antibody used at 1:100dilution. Samples were run on the flow cytometer (Beckman Coulter EPICS XL flow cytometer) and post-acquisition analysis was performed with Flowjo (Version 8.7.1).

\section{Ethidium Homodimer-1}

To measure total cell death, time lapse imaging of cells in monoculture and competition was performed using a nonspecific marker for cell death, ethidium homodimer1 (Invitrogen). This assay has the advantage of measuring all forms of cell death, not just apoptosis. Competitions were established in 6 -well plates using the methodology described above and $2.5 \mu \mathrm{M}$ ethidium homodimer- 1 added to the culture 24 hours following cell seeding. Immediately following the addition of the ethidium homodimer, plates were imaged using a Nikon TE300 inverted microscope equipped with a motorized $\mathrm{XY}$ stage and Environmental chamber (Temperature and $\mathrm{CO}_{2}$ control surrounding entire microscope). Image Pro 6.2 was used for image acquisition and also controls the motorized stage, filter wheels, shutters, and lamp settings. Using the automated stage macro, twelve areas selected, 2 fields per well, locations in any $\mathrm{X}, \mathrm{Y}$, or $\mathrm{Z}$ direction saved. Two images from the same position in each well were taken every 15 minutes for a total of 48 hours with a Q-imaging retiga EX digital camera. Percent death statistics were calculated by manually tracing cell fates in each time laps experiment for 240-455 cells per condition.

\section{Statistical Analysis}

Statistical significance was evaluated using the R statistics software by a series of t-tests comparing the difference in proportion of $\mathrm{BE}$ cells between day 0 and day 14 at $0 \mu \mathrm{M}$ and $500 \mu \mathrm{M}$ Vitamin C. Using a Bonferroni correction for multiple testing, comparisons with a pvalue less than 0.00625 were considered significant.

\section{Results}

\section{Competitions under varying levels of Vitamin $C$}

Four unlabeled BE cell lines (CP-A, CP-B, CP-C, and CP-D) were tested in co-culture competition (Figure 1) against a stably-transduced eGFP-labeled normal esophageal squamous cell line (EPC2). The effect of vitamin $\mathrm{C}$ exposure varied between cell lines. There is a statistically significant reduction in BE cells at $500 \mu \mathrm{M}$ ascorbic acid relative to the $0 \mu \mathrm{m}$ treatment for $\mathrm{CP}-\mathrm{B}$ and $\mathrm{CP}-\mathrm{C}$ cell lines (Figure 2B, C), demonstrating that the presence of Vitamin $\mathrm{C}$ gives the EPC2 squamous cells a relative competitive advantage. This trend is also apparent in the CP-A cell line (Figure 2A), although this is not statistically significant under the conservative Bonferroni multiple testing correction. While we find that

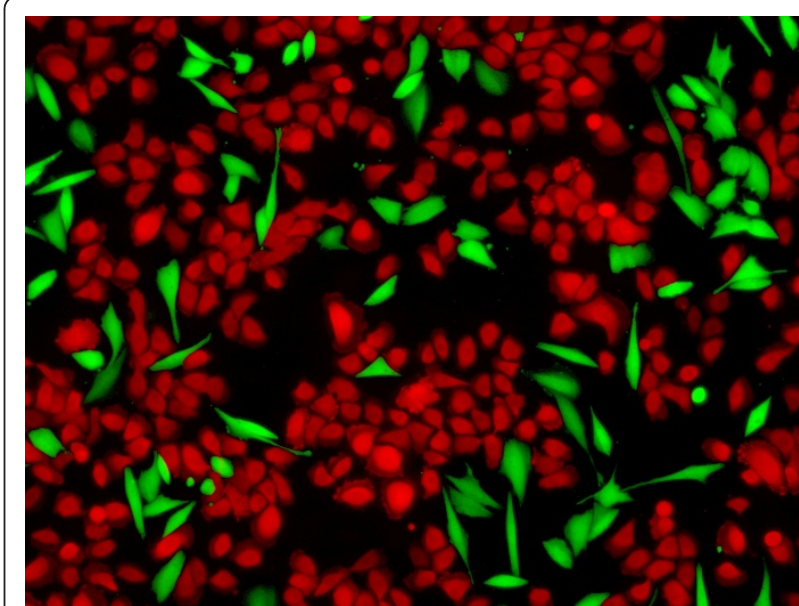

Figure 1 Cell culture competition. Image of competition between Barrett's esophagus cell line CP-D (green) and normal squamous cell line EPC2 (red). Cells are grown until they begin to approach confluency and are then passaged to maintain logarithmic growth. Both cell lines are labeled here for imaging purposes, however, in standard competitions BE cell lines are unlabeled. Note that the green cells do not necessarily grow in contiguous patches, and so there must either be cell migration or a process of detachment and reattachment as those clones expand. The two cell types can interact both by physical contact and via secreted factors.

squamous cells more rapidly outcompete BE cells in the presence of vitamin $C$, this effect is often not dosedependent. The CP-B cell line shows a particularly noteworthy saturation effect in both the no-acid and acidpulsed competitions (Figure 2B, 3B), with lower concentrations of ascorbic acid providing a greater competitive advantage to the squamous cells.

\section{Acid-pulsed competitions under varying levels of Vitamin C}

To better simulate the phenomenon of acid reflux associated with BE (a potential cause of the condition), competitions were exposed to $\mathrm{pH} 3.5$ PBS for 6 minutes daily. With daily acid pulses, the difference between the 0 and $500 \mu \mathrm{M}$ ascorbic acid treatments is generally magnified, with CP-A, CP-C, and CP-D cell lines all showing a decrease in $\mathrm{BE}$ cell lines with Vitamin $\mathrm{C}$ present (Figure 3). This effect occurred in a dose-dependent manner. No systematic effect of vitamin C on the CP-B cell line can be detected under acidic conditions. Again, it appears that high levels of vitamin $C$ ameliorate the competitive advantage of the EPC2 cells compared with the BE cells as lower levels of vitamin $C$ do show a substantial effect on competitions between EPC2 and CP-B cells (Figure 3B). Generally, the addition of acid alone favors the BE cells, but the combination of acid and vitamin $\mathrm{C}$ results in conditions less favorable for $\mathrm{BE}$ cells and more favorable for squamous cells. 


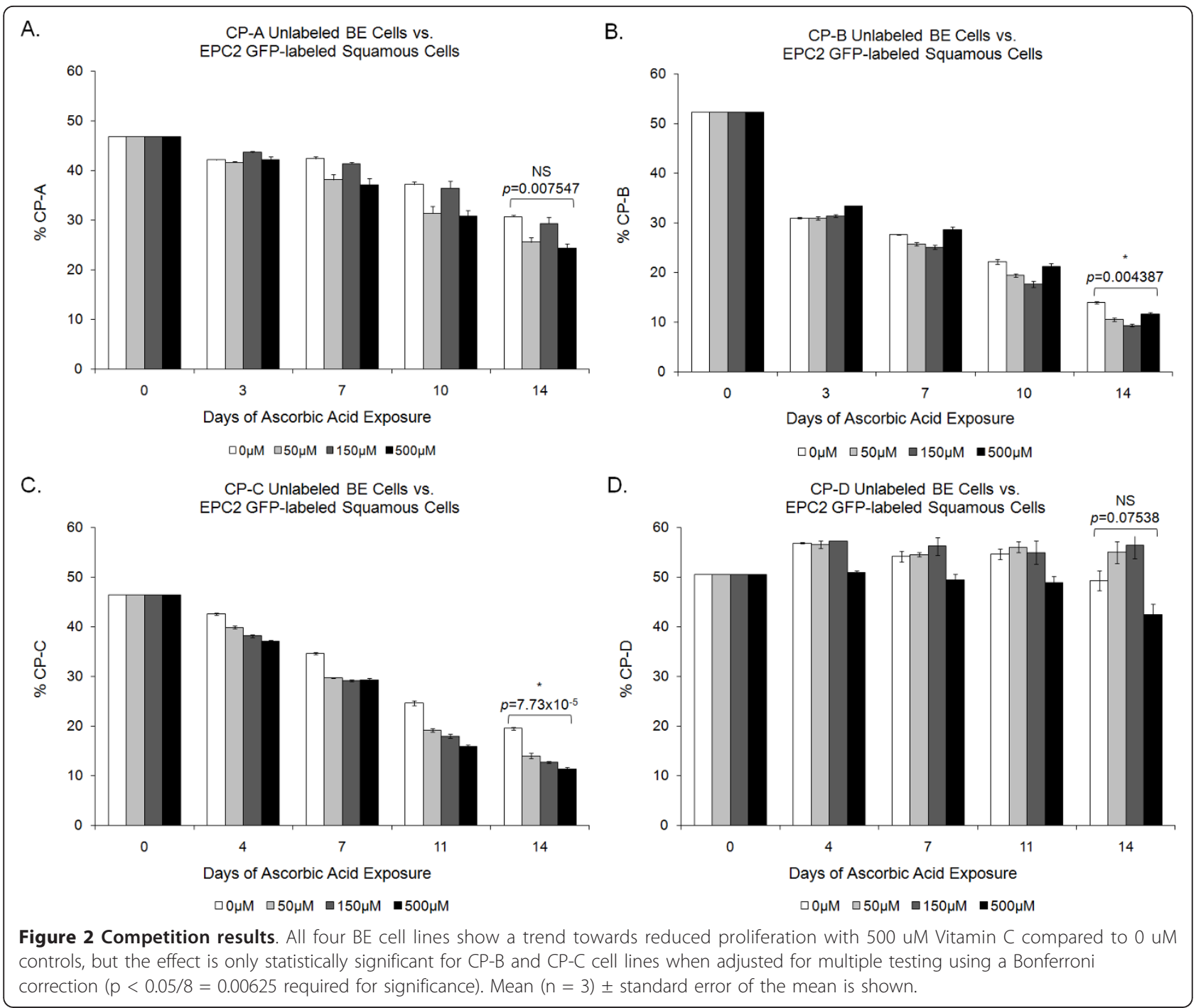

\section{Growth of cell lines in monoculture}

Monoculture experiments (Figure 4) demonstrate that vitamin $C$ reduces the net growth for both the squamous and Barrett's cell lines. It is important to note that the monoculture results alone do not explain the results of the competition. In monoculture, for example, the CP-C cell line grows as well or better than the EPC2 squamous line, but in competition the squamous cells quickly outcompete the $\mathrm{CP}-\mathrm{C}$ cells. It is clear from examination of the monoculture data that the cell lines described here are not acting independently when grown in competition, therefore monoculture data does not accurately describe the co-culture environment. Cell culture competition models are able to capture interactions between different cell types in a way that a monoculture model cannot. This provides direct evidence that competition dynamics are present in the co-culture environment.
Competitions under varying levels of Vitamin E and EGF

Competitions were also performed with varying levels of Vitamin E and EGF (Additional File 1, Figures S2-S3). EGF did not have a significant effect on the outcome of competition. In the case of vitamin E, very high levels of $\alpha$-tocopherol strongly suppressed growth of both cell lines. Unexpectedly, the fitness of the squamous cells was more strongly suppressed by vitamin $\mathrm{E}$ than the $\mathrm{BE}$ cells with the end result that BE cells out-compete squamous cells at high concentrations of Vitamin E (Additional File 1, Figure S2). Lower levels of Vitamin E did not affect the outcome of competition.

\section{Apoptosis and Proliferation Assays on Vitamin C Competitions}

Cell culture competitions provide a window into the net growth of the cells under the conditions defined by the investigator, but they do not identify the 


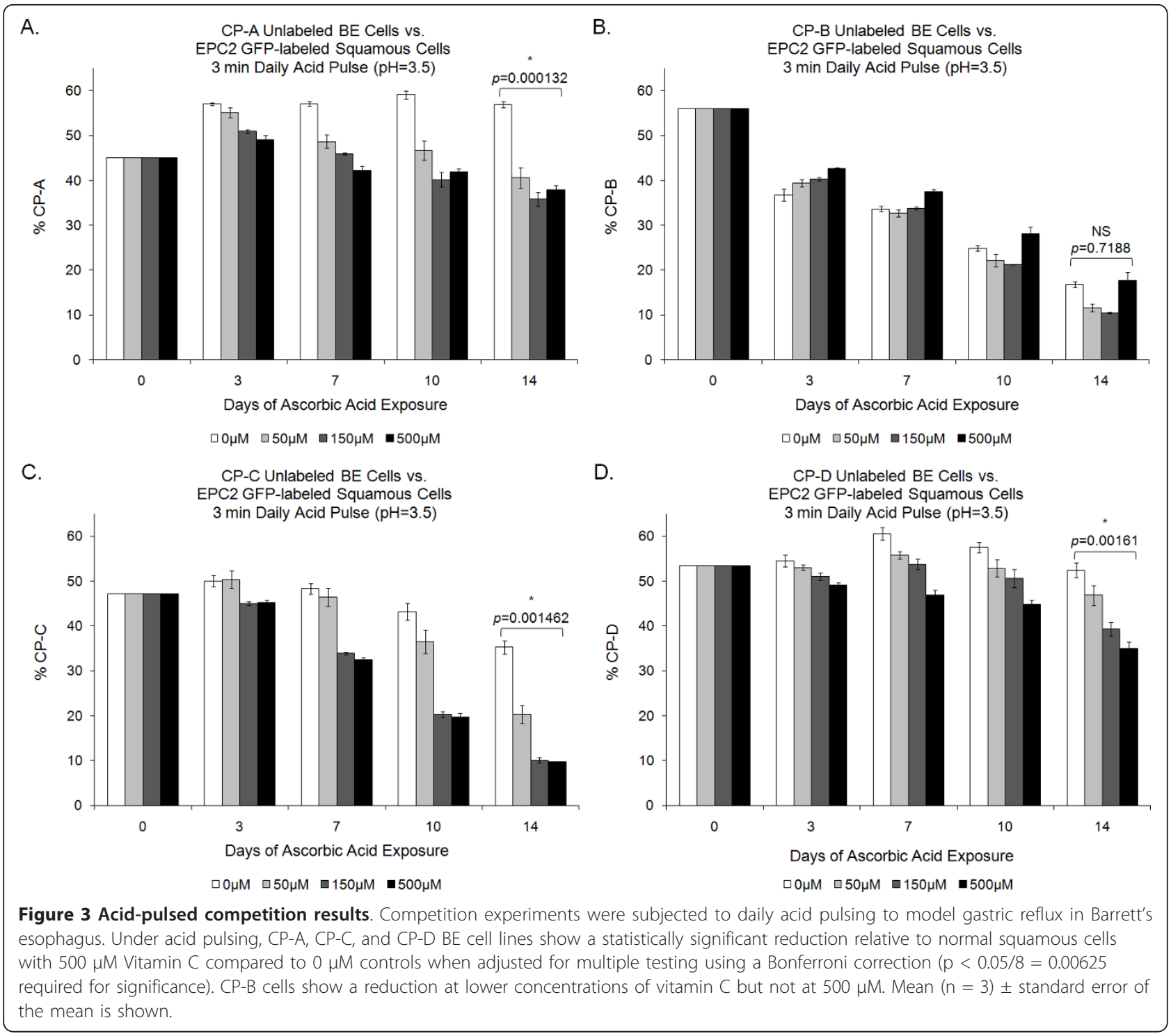

mechanism of the fitness effect. While it is clear that vitamin $C$ increases the overall proportion of squamous cells relative to Barrett's cells, it is not clear if this is due to an increase in proliferation/survival of the squamous cells or a reduction in proliferation/survival in BE cell lines.

To determine if the effects of vitamin $C$ in the competition between EPC2 squamous cells and CP-C cells was due to changes in proliferation, differences in levels of phosphorylated serine 10 on histone $\mathrm{H} 3$ ( $\mathrm{PHH} 3$ ) were measured by flow cytometry. Phosphorylated serine 10 on histone $\mathrm{H} 3$ is a marker of mitotic cells. Although the proportion of $\mathrm{PHH} 3+$ cells was extremely low, we were able to show reduced proliferation of the CP-C cells under $500 \mu \mathrm{M}$ ascorbic acid conditions for two separate experiments (Table 1). We did not find a systematic change in proliferation of EPC2 cells with ascorbic acid (data not shown). Several apoptosis assays (cleaved caspase-3, annexin-V+7AAD, TUNEL) were also performed; however, little apoptosis was detected in this system. Because the media which overlays the cells in the competitions is changed every 2-3 days, many apoptotic cells are likely lost as the competition progresses. The caspase- 3 assays do hint at an increased apoptosis level for both EPC2 and CP-C cell lines but the total amount of apoptotic cells is very low $(<0.1 \%$, Additional File 1, Figure S4). To overcome the limitation incurred by extrusion of apoptotic cells into the surrounding media, time lapse imaging of cells in competition in the presence of ethidium homodimer-1 was performed. No systematic differences in cell death in the presence of $500 \mu \mathrm{M}$ vitamin $\mathrm{C}$ were detected, nor were there 


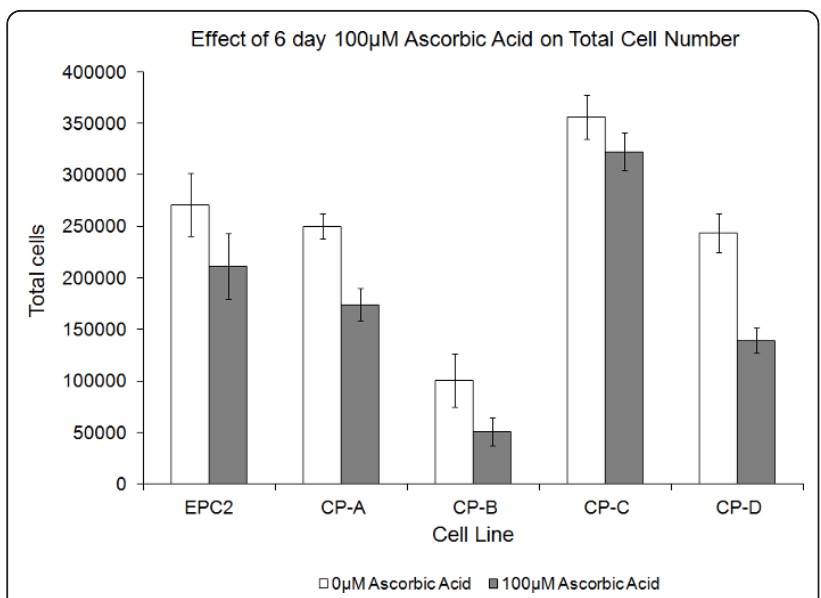

Figure 4 Effect of Vitamin C Exposure on Cell Number. The squamous and Barrett's cell lines all show a reduction in average cell number with Vitamin $C$ exposure compared to control conditions. Mean of $n \geq 6 \pm$ standard error of the mean is shown.

differences in total cell death between monoculture and competition (Additional File 1, Figure S5).

We also confirmed that the effect was not due simply to serial passaging of the cells. We were initially concerned that if cell lines adhere to cell culture dishes at varying rates during reseeding, there might be differences in the lag time before exponential growth could resume that might account for differences seen between cell lines in competition. This was of particular concern with vitamin $C$, which can affect extracellular matrix components [45]. We found no significant differences in "lag time", the time between trypsinization and resumption of exponential growth, between the different cell lines following trypsinization and replating (data not shown).

\section{Discussion}

We have developed a sensitive and robust in vitro model of the process of cellular competition, which is thought to drive the evolution of malignancy [1]. The utility of our assay is demonstrated in proof of principle experiments with ascorbic acid, where we find that vitamin $C$ increases the fitness of esophageal squamous cells relative to Barrett's esophagus cells.

Table 1 CP-C Unlabeled BE cells vs. EPC2 DsRed-labeled Squamous Cells

\begin{tabular}{ccc}
\hline Experiment & Concentration Vitamin C & $\begin{array}{c}\text { Average CP-C \% } \text { PHH3 }^{+} \\
(\mathbf{n}=\mathbf{2})\end{array}$ \\
\hline 1 & $0 \mu \mathrm{M}$ & 2.64 \\
& $500 \mu \mathrm{M}$ & 2.31 \\
2 & $0 \mu \mathrm{M}$ & 1.32 \\
& $500 \mu \mathrm{M}$ & 0.91 \\
\hline
\end{tabular}

The methodology for cell competition is based on bacterial batch culture competition models [46], in which cells are maintained in logarithmic growth and serially passaged. Human cell culture is more complicated than a simple bacterial batch culture system due to the substantially greater potential for interactions between cell lines via mechanisms such as diffusible growth factors, ECM interactions and contact inhibition, although these phenomena are certainly possible in bacterial systems as well $[47,48]$.

The cell culture competition model allows us to capture the relative effect of a compound on 2 cell lines of interest simultaneously. It is this effect, rather than the absolute growth rate, that is most important physiologically as different cell types likely interact with one another. This phenomenon is of particular relevance in Barrett's esophagus, where there is a clear junction between Barrett's cells and normal squamous esophageal cells. It is important to note that in the experiments described here, the normal squamous esophageal cells outcompete the $\mathrm{BE}$ cells under almost all concentrations of vitamin $C$. Therefore, we are comparing the relative rate at which the squamous cells outcompete the $\mathrm{BE}$ cells under different concentrations of vitamin C. This baseline advantage of the squamous lines in this system is likely an artifact of the cell culture conditions used. Here, all cells are grown in the serum-free media most suitable for the growth of the normal esophageal squamous cells. The addition of serum in the media leads to increased relative fitness of BE cells compared to noserum controls in all cell lines tested. In 2 out of 3 cell lines, this increase is such that the BE cells outcompete the squamous cells as would be expected under in vivo conditions (Additional File 1, Figure S6). Future models of competition might be developed with a more realistic microenvironment using three-dimensional organotypic cultures that include both extracellular matrix and stromal cells [49-51].

The mechanism of the cancer preventive effect of vitamin $C$ is thought to be via a reduction of reactive oxygen species (ROS). BE is associated with chronic inflammation, which can generate ROS, thought to contribute to the development of a variety of cancers. A meta-analysis and other recent studies have reported that intake of antioxidants such as vitamin C, E, and beta-carotene are inversely associated with risk of esophageal adenocarcinoma [39,40]. While it is clear that there is some relationship between the concentration of antioxidants and BE [e.g. [43]], substantial further experimentation would be required to fully characterize vitamin $C$ as a preventive agent. In general, patients with EA have been found to have lower intakes of antioxidants compared to control populations [52]. Recent studies have shown that BE patients have significantly 
lower plasma levels of vitamin $\mathrm{C}$ (ascorbic acid), xanthophylls and other antioxidants [43]. In addition to lower plasma levels, BE mucosa was found to contain significantly lower levels of vitamin $\mathrm{C}$ compared with matched normal squamous mucosa [44]. This reduced presence of exogenous antioxidants may enhance the effects of DNA-damaging oxygen radicals.

Reduction of vitamin $\mathrm{C}$ in patients with $\mathrm{BE}$ may come from both a diet low in antioxidants as well as a reduced absorption of vitamin $C$ from the stomach [39]. Vitamin $\mathrm{C}$ is unstable at non-acidic $\mathrm{pH}$ and patients on proton pump inhibitors, such as omeprazole, have more basic gastric fluid. In one study [53], individuals given $40 \mathrm{mg} /$ day for 28 days of omeprazole had a $12.3 \%$ decrease in plasma vitamin $\mathrm{C}$ levels independent of dietary vitamin $C$ intake, suggesting that there may be lowered bioavailability of vitamin $C$ in patients currently prescribed proton pump inhibitors (PPI). It warrants further investigation whether the current standard of care for individuals with BE, PPI medication (with regular endoscopic surveillance), is promoting reduced levels of vitamin $\mathrm{C}$ and whether this may, in turn, promote expansion of the Barrett's segment.

We view these cell culture competition models as particularly useful for early screens of chemoprevention agents, particularly when there are few model systems available, as in the case of BE. Many drugs have subtle effects and this system allows for longitudinal measurement of the effects of various compounds on cell competition. Our model is able to integrate differential fitness effects on both normal and neoplastic cells, regardless of whether they act through decreasing the fitness of neoplastic cells or increasing the fitness of normal cells, and so may be useful for the discovery of new classes of drugs, such as benign cell boosters [2]. In order to screen any large number of therapeutic agents, our model would have to be downscaled to run in 96or 384-well plates. This is a simple assay designed for an initial screen, performed on plastic in 2D culture, but it can provide preliminary data for more complex animal model testing and for exploration of epidemiologic results.

\section{Conclusions}

We established a cell culture model that can capture the dynamics of competition between two interacting cell lines. Because it is this interaction between normal and neoplastic cells that is the basis for our cancer prevention and therapy interventions, this model can provide an initial screen of potential compounds. We show that ascorbic acid is a modulator of competition between esophageal squamous cells and Barrett's esophagus cells. The advantage of squamous cells relative to Barrett's cells is enhanced by the addition of acid pulses mimicking the reflux conditions of the distal esophagus.

\section{Additional material}

Additional file 1: Supplemental information Sections 1-6

\section{Acknowledgements}

We would like to thank James Hayden and Fred Keeney of the Wistar Institute microscopy facility and the staff of the Wistar Institute Flow Cytometry facility for their invaluable assistance. This work was funded by a Landon AACR Innovator Award for Cancer Prevention, NIH grants R01CA140657, R01 CA119224, P01CA091955, R03CA137811, Wistar Cancer Center P30 CA010815, Research Scholar Grant \#117209-RSG-09-163-01-CNE from the American Cancer Society, the Pew Charitable Trust and NIH postdoctoral fellowship F32 CA132450.

\section{Author details}

${ }^{1}$ The Wistar Institute, 3601 Spruce St., Philadelphia, PA 19104, USA. ${ }^{2}$ Cell and Molecular Biology Program, University of Pennsylvania, 451 Curie Blvd, Philadelphia, PA 19104, USA. ${ }^{3}$ Helen Diller Family Comprehensive Cancer Center, Department of Surgery, University of California, San Francisco, 2340 Sutter St., San Francisco, CA 94115, USA.

\section{Authors' contributions}

CM conceived of idea. CM, LM and RK planned all experiments. Competition experiments were performed by RK, LM, and KG. RK and KG carried out proliferation and apoptosis assays. LM performed time lapse imaging. LM performed all statistical analyses and wrote the manuscript. All authors read and approved the final manuscript.

\section{Competing interests}

The authors declare that they have no competing interests.

Received: 7 April 2011 Accepted: 25 October 2011

Published: 25 October 2011

\section{References}

1. Merlo LMF, Pepper JW, Reid BJ, Maley CC: Cancer as an evolutionary and ecological process. Nat Rev Cancer 2006, 6:924-935.

2. Maley CC, Reid BJ, Forrest S: Cancer prevention strategies that address the evolutionary dynamics of neoplastic cells: simulating benign cell boosters and selection for chemosensitivity. Cancer Epidemiol Biomarkers Prev 2004, 13:1375-1384.

3. Galipeau PC, Prevo LJ, Sanchez CA, Longton GM, Reid BJ: Clonal expansion and loss of heterozygosity at chromosomes $9 p$ and $17 p$ in premalignant esophageal (Barrett's) tissue. J Natl Cancer Inst 1999, 91:2087-2095.

4. Wong DJ, Paulson TG, Prevo LJ, Galipeau PC, Longton G, Blount PL, Reid BJ: p16(INK4a) lesions are common, early abnormalities that undergo clonal expansion in Barrett's metaplastic epithelium. Cancer Res 2001, 61:8284-8289.

5. Siegmund KD, Marjoram P, Tavaré S, Shibata D: Many colorectal cancers are "flat" clonal expansions. Cell Cycle 2009, 8:2187-2193.

6. Majewski T, Lee S, Jeong J, Yoon DS, Kram A, Kim MS, Tuziak T, Bondaruk J, Lee S, Park WS, Tang KS, Chung W, Shen L, Ahmed SS, Johnston DA, Grossman HB, Dinney CP, Zhou JH, Harris RA, Snyder C, Filipek S, Narod SA, Watson P, Lynch HT, Gazdar A, Bar-Eli M, Wu XF, McConkey DJ, Baggerly K, Issa JP, Benedict WF, Scherer SE, Czerniak B: Understanding the development of human bladder cancer by using a whole-organ genomic mapping strategy. Lab Invest 2008, 88:694-721.

7. Miller BE, Miller FR, Heppner GH: Therapeutic perturbation of the tumor ecosystem in reconstructed heterogeneous mouse mammary tumors. Cancer Res 1989, 49:3747-3753.

8. Miller BE, Machemer T, Lehotan M, Heppner GH: Tumor subpopulation interactions affecting melphalan sensitivity in palpable mouse mammary tumors. Cancer Res 1991, 51:4378-4387. 
9. Heng HHQ, Bremer SW, Stevens JB, Ye KJ, Liu G, Ye CJ: Genetic and epigenetic heterogeneity in cancer: a genome-centric perspective. J Cell Physiol 2009, 220:538-547.

10. Caignard A, Martin MS, Michel MF, Martin F: Interaction between two cellular subpopulations of a rat colonic carcinoma when inoculated to the syngeneic host. Int J Cancer 1985, 36:273-279.

11. Guba M, Cernaianu G, Koehl G, Geissler EK, Jauch KW, Anthuber M, Falk W, Steinbauer M: A primary tumor promotes dormancy of solitary tumor cells before inhibiting angiogenesis. Cancer Res 2001, 61:5575-5579.

12. Miller BE, Miller FR, Leith J, Heppner GH: Growth interaction in vivo between tumor subpopulations derived from a single mouse mammary tumor. Cancer Res 1980, 40:3977-3981.

13. Baker NE, Li W: Cell competition and its possible relation to cancer. Cancer Res 2008, 68:5505-5507.

14. Heppner G, Miller B, Cooper DN, Miller FR: Growth interactions between mammary tumor cells. In Cell Biology of Breast Cancer. Edited by: McGrath C, Brennan M, Rich M. New York: Acadmic Press; 1980:161-172.

15. Tamori Y, Bialucha CU, Tian AG, Kajita M, Huang YC, Norman M, Harrison N, Poulton J, Ivanovitch K, Disch L, Liu T, Deng WM, Fujita Y: Involvement of Lgl and Mahjong/VprBP in cell competition. PLoS Biol 2010, 8:e1000422.

16. Bozic I, Antal T, Ohtsuki H, Carter H, Kim D, Chen S, Karchin R, Kinzler KW, Vogelstein B, Nowak MA: Accumulation of driver and passenger mutations during tumor progression. Proc Natl Acad Sci USA 2010, 107:18545-18550.

17. Hogan C, Kajita M, Lawrenson K, Fujita Y: Interactions between normal and transformed epithelial cells: Their contributions to tumourigenesis. Int J Biochem Cell Biol 2011, 43:496-503.

18. Hogan C, Dupré-Crochet S, Norman M, Kajita M, Zimmermann C, Pelling AE, Piddini E, Baena-López LA, Vincent JP, Itoh Y, Hosoya H, Pichaud F, Fujita Y: Characterization of the interface between normal and transformed epithelial cells. Nat Cell Biol 2009, 11:460-467.

19. Kajita M, Hogan C, Harris AR, Dupre-Crochet S, Itasaki N, Kawakami K, Charras G, Tada M, Fujita Y: Interaction with surrounding normal epithelial cells influences signalling pathways and behaviour of Src-transformed cells. J Cell Sci 2010, 123:171-180.

20. Moreno E, Basler K: dMyc transforms cells into super-competitors. Cell 2004, 117:117-129.

21. Baker NE: Cell competition. Curr Biol 2011, 21:R11-15.

22. Moreno E: Is cell competition relevant to cancer? Nat Rev Cancer 2008, 8:141-147.

23. de la Cova C, Abril M, Bellosta P, Gallant P, Johnston LA: Drosophila myc regulates organ size by inducing cell competition. Cell 2004, 117:107-116.

24. Vincent JP, Kolahgar G, Gagliardi M, Piddini E: Steep differences in wingless signaling trigger myc-independent competitive cell interactions. Dev Cell 2011, 21:366-374.

25. Senoo-Matsuda N, Johnston LA: Soluble factors mediate competitive and cooperative interactions between cells expressing different levels of Drosophila Myc. Proc Natl Acad Sci USA 2007, 104:18543-18548.

26. Reid BJ, Li X, Galipeau PC, Vaughan TL: Barrett's oesophagus and oesophageal adenocarcinoma: time for a new synthesis. Nat Rev Cancer 2010, 10:87-101.

27. Paulson TG, Xu L, Sanchez C, Blount PL, Ayub K, Odze RD, Reid BJ: Neosquamous epithelium does not typically arise from Barrett's epithelium. Clin Cancer Res 2006, 12:1701-1706.

28. Spechler SJ, Fitzgerald RC, Prasad GA, Wang KK: History, molecular mechanisms, and endoscopic treatment of Barrett's esophagus. Gastroenterology 2010, 138:854-869.

29. Haggitt RC: Barrett's esophagus, dysplasia, and adenocarcinoma. Hum Pathol 1994, 25:982-993.

30. Thomas T, Abrams KR, De Caestecker JS, Robinson RJ: Meta analysis: Cancer risk in Barrett's oesophagus. Aliment Pharmacol Ther 2007, 26:1465-1477.

31. Yousef F, Cardwell C, Cantwell MM, Galway K, Johnston BT, Murray L: The incidence of esophageal cancer and high-grade dysplasia in Barrett's esophagus: a systematic review and meta-analysis. Am J Epidemiol 2008, 168:237-249.

32. Chen X, Qin R, Liu B, Ma Y, Su Y, Yang CS, Glickman JN, Odze RD, Shaheen NJ: Multilayered epithelium in a rat model and human Barrett's esophagus: similar expression patterns of transcription factors and differentiation markers. BMC Gastroenterol 2008, 8:1.
33. Bonde P, Sui G, Dhara S, Wang J, Broor A, Kim IF, Wiley JE, Marti G, Duncan M, Jaffee E, Montgomery E, Maitra A, Harmon JW: Cytogenetic characterization and gene expression profiling in the rat reflux-induced esophageal tumor model. J Thorac Cardiovasc Surg 2007, 133:763-769.

34. Buskens CJ, Hulscher JBF, van Gulik TM, Ten Kate FJ, van Lanschot JJB: Histopathologic evaluation of an animal model for Barrett's esophagus and adenocarcinoma of the distal esophagus. J Surg Res 2006, 135:337-344

35. Su Y, Chen X, Klein M, Fang M, Wang S, Yang CS, Goyal RK: Phenotype of columnar-lined esophagus in rats with esophagogastroduodenal anastomosis: similarity to human Barrett's esophagus. Lab Invest 2004, 84:753-765.

36. Buttar NS, Wang KK, Leontovich O, Westcott JY, Pacifico RJ, Anderson MA, Krishnadath KK, Lutzke LS, Burgart LJ: Chemoprevention of esophageal adenocarcinoma by COX-2 inhibitors in an animal model of Barrett's esophagus. Gastroenterology 2002, 122:1101-1112.

37. Kwak EL, Jankowski J, Thayer SP, Lauwers GY, Brannigan BW, Harris PL, Okimoto RA, Haserlat SM, Driscoll DR, Ferry D, Muir B, Settleman J, Fuchs CS, Kulke MH, Ryan DP, Clark JW, Sgroi DC, Haber DA, Bell DW: Epidermal growth factor receptor kinase domain mutations in esophageal and pancreatic adenocarcinomas. Clin Cancer Res 2006, 12:4283-4287.

38. Rygiel AM, Milano F, Ten Kate FJ, Schaap A, Wang KK, Peppelenbosch MP, Bergman JJGHM, Krishnadath KK: Gains and amplifications of c-myc, EGFR, and 20.q13 loci in the no dysplasia-dysplasia-adenocarcinoma sequence of Barrett's esophagus. Cancer Epidemiol Biomarkers Prev 2008, 17:1380-1385.

39. Kubo A, Corley DA: Meta-analysis of antioxidant intake and the risk of esophageal and gastric cardia adenocarcinoma. Am J Gastroenterol 2007 102:2323-2330, quiz 2331

40. Dong LM, Kristal AR, Peters U, Schenk JM, Sanchez CA, Rabinovitch PS Blount PL, Odze RD, Ayub K, Reid BJ, Vaughan TL: Dietary supplement use and risk of neoplastic progression in esophageal adenocarcinoma: a prospective study. Nutr Cancer 2008, 60:39-48.

41. Palanca-Wessels MC, Barrett MT, Galipeau PC, Rohrer KL, Reid BJ, Rabinovitch PS: Genetic analysis of long-term Barrett's esophagus epithelial cultures exhibiting cytogenetic and ploidy abnormalities. Gastroenterology 1998, 114:295-304.

42. Palanca-Wessels MCA, Klingelhutz A, Reid BJ, Norwood TH, Opheim KE, Paulson TG, Feng Z, Rabinovitch PS: Extended lifespan of Barrett's esophagus epithelium transduced with the human telomerase catalytic subunit: a useful in vitro model. Carcinogenesis 2003, 24:1183-1190.

43. Clements DM, Oleesky DA, Smith SC, Wheatley H, Hullin DA, Havard TJ, Bowrey DJ: A study to determine plasma antioxidant concentrations in patients with Barrett's oesophagus. J Clin Pathol 2005, 58:490-492.

44. Fountoulakis A, Martin IG, White KLM, Dixon MF, Cade JE, Sue-Ling HM, Wild CP: Plasma and esophageal mucosal levels of vitamin C: role in the pathogenesis and neoplastic progression of Barrett's esophagus. Dig Dis Sci 2004, 49:914-919.

45. Labat-Robert J, Robert L: The effect of cell-matrix interactions and aging on the malignant process. Adv Cancer Res 2007, 98:221-259.

46. Lenski $R$, Rose M, Simpson S, Tadler : Long-term experimental evolution in Escherichia coli. I. Adaptation and divergence during 2,000 generations. American Naturalist 1991, 138:1315-1341.

47. Rosenzweig RF, Sharp RR, Treves DS, Adams J: Microbial evolution in a simple unstructured environment: genetic differentiation in Escherichia coli. Genetics 1994, 137:903-917.

48. Czárán TL, Hoekstra RF, Pagie L: Chemical warfare between microbes promotes biodiversity. Proc Natl Acad Sci USA 2002, 99:786-790.

49. Andl CD, Mizushima T, Nakagawa H, Oyama K, Harada H, Chruma K, Herlyn M, Rustgi AK: Epidermal growth factor receptor mediates increased cell proliferation, migration, and aggregation in esophageal keratinocytes in vitro and in vivo. J Biol Chem 2003, 278:1824-1830.

50. Kalabis J, Patterson MJ, Enders GH, Marian B, lozzo RV, Rogler G, Gimotty PA, Herlyn M: Stimulation of human colonic epithelial cells by leukemia inhibitory factor is dependent on collagen-embedded fibroblasts in organotypic culture. FASEB J 2003, 17:1115-1117.

51. Smalley KSM, Lioni M, Herlyn M: Life isn't flat: taking cancer biology to the next dimension. In Vitro Cell Dev Biol Anim 2006, 42:242-247. 
52. Terry $\mathrm{P}$, Lagergren J, Hansen $\mathrm{H}$, Wolk A, Nyrén O: Fruit and vegetable consumption in the prevention of oesophageal and cardia cancers. Eur $\lrcorner$ Cancer Prev 2001, 10:365-369.

53. Henry EB, Carswell A, Wirz A, Fyffe V, McColl KEL: Proton pump inhibitors reduce the bioavailability of dietary vitamin C. Aliment Pharmacol Ther 2005, 22:539-545.

\section{Pre-publication history}

The pre-publication history for this paper can be accessed here: http://www.biomedcentral.com/1471-2407/11/461/prepub

doi:10.1186/1471-2407-11-461

Cite this article as: Merlo et al:: An in vitro co-culture model of esophageal cells identifies ascorbic acid as a modulator of cell competition. BMC Cancer 2011 11:461.

Submit your next manuscript to BioMed Central and take full advantage of:

- Convenient online submission

- Thorough peer review

- No space constraints or color figure charges

- Immediate publication on acceptance

- Inclusion in PubMed, CAS, Scopus and Google Scholar

- Research which is freely available for redistribution

Submit your manuscript at www.biomedcentral.com/submit 